\title{
Rewitalizacja obszarów nadrzecznych w przestrzeniach miejskich
} Urban regeneration of riverside areas in urban spaces

\begin{abstract}
STRESZCZENIE
Artykuł przybliża tematykę zagospodarowania obszarów nadrzecznych co jest obecnie jednym z największych wyzwań urbanistycznych dla współczesnych miast. Problem wpisuje się w nurt rozwoju zrównoważonego. W badaniach skupiono się na wykazaniu korzyści zarówno ekonomicznych jak i społecznych wynikających z odpowiednio zagospodarowanych terenów nabrzeży rzek poprzez zainteresowanie inwestorów, turystów, ale przede wszystkim samych mieszkańców miasta.
\end{abstract}

\begin{abstract}
The article is meant to familiarise readers with the subject of the development of riverfronts, which is currently one of the greatest urban planning challenges for contemporary cities. The problem is within the scope of sustainable development. The research focused on demonstrating both the economic and social benefits that are the direct result of appropriately development riverfront areas as they inspire interest in them in developers, tourists and, primarily, city residents themselves.
\end{abstract}

Słowa kluczowe: obszary nadbrzeżne, rewitalizacja, eko-expo

Keywords: riverfront areas, revitalisation, eco-expo

\section{Wstęp}

Rewitalizacja to z łaciny dosłownie - przywrócenie do życia, ożywienie. Rewitalizacja jest próbą ponownego zaktywizowania utraconej przestrzeni miasta, to proces przemian przestrzennych, społecznych oraz ekonomicznych, które przyczyniają się do poprawy jakości miejsca. Ma też istotny wpływ na ożywienie gospodarcze i odbudowę relacji społecznych na terenach zdegradowanych. ${ }^{1}$ Tereny nadrzeczne należą do najwcześniej użytkowanych i przeobrażanych przez ludzi fragmentów krajobrazu naturalnego. Położenie nad rzeką było olbrzymią zaletą - wiązało się z możliwością rozwoju osadnictwa. Człowiek wykorzystywał te atuty i przekształcał naturę według swoich potrzeb. Niestety często ekspansywna działalność ludzi przyczyniła się do dewastacji terenów nadrzecznych, kompletnego ich "wyjałowienia" oraz sprawiła, iż obszary te przestały być atrakcyjne. Jednakże w ciągu ostatnich dekad nastąpił "renesans nabrzeży", który przybrał ogólnoświatowy wymiar. ${ }^{2}$ Dzięki dobrze przeprowadzonej i przemyślanej rewitalizacji, tereny nadrzeczne mają szansę stać się strefą ożywienia społeczno-gospodarczego, która będzie wizytówką miasta, fragmentem przestrzeni miejskiej, która przyciągnie zarówno turystów jak i potencjalnych inwestorów. Są też szansą dla mieszkańców na uzyskanie atrakcyjnych tere-

\section{Introduction}

Revitalisation, from Latin, literally means to bring something back to life. Revitalisation, also called urban regeneration, is an attempt at reactivating a space that has been lost to the city, It is a process of spatial, social and economic change which leads to the improvement of the quality of a place. It also has a significant impact on economic stimulation and the rebuilding of social relations within the decayed area'. Riverside areas belong to some of the first fragments of the natural landscape that have been used and transformed by man. Riverside locations were immensely beneficial-they made settlement possible. Man used these advantages and transformed nature in accordance with his needs. Unfortunately, man's expansive activities often led to the devastation of riverside areas, making them completely "barren", and led to these areas no longer being attractive. However, over the last few decades, a "Riverside Renaissance" has taken place, taking on the form of a global phenomenon ${ }^{2}$. Thanks to a wellcarried out and well-thought out urban regeneration, riverside areas have a chance to become zones of socio-economic stimulation, which can become the hallmark of the city, a fragment of urban space that attracts both tourists and potential investors. They are also a chance for residents to obtain attractive ar- 
nów rekreacji i odpoczynku, a przez swoisty mikroklimat, poprawe jakości powetrza w mieście. To sprawia, że powiązanie miasta z rzeką jest jednym z głównych wyzwań z którymi musza zmierzyć sie miasta nadrzeczne. Istotne jest jednak, aby działania zostały przeprowadzone w sposób skoordynowany z udziałem władz samorzadowych, prywatnych inwestorów, ale również przyszłych użytkowników przekształcanego terenu, by dokonan zmiany nie były oderwane od ich oczekiwań i potrzeb.

\section{Przykłady rewitalizacji obszarów nadbrzeżnych} 2.1. Promenada Samuel-de Champlain w Ouebec ${ }^{3}$ Interesującym przykładem zagospodarowania obszarów nadrzecznych, ze względu na odpowiednio przemyślany układ funkcjonalny i powiazania przestrzenne, jest promenada Samuela de Champaina w mieście Quebec w Kanadzie. Deptak został zrealizowany z okazji 400-lecia miasta i jest niejako przestrzennym pomnikiem dla de Camplaina. Podróżnik założył tutaj fort, który przez lata przekształcił się w 500-tysięczne miasto. Projekt zakłada odzyskanie zaniedbanego terenu przemystowego i przekształcenie go w publiczny, rekreacyjny obszar, który zwróci miasto $w$ kierunku rzeki.

Jedną z najważniejszych rzeczy, z jaką musieli się zmierzyć architekci, bylo przeprojektow strad, które przecinały ten teren na całej długości. Drugą było uczynienie tej ogromnej przestrzeni wygodna atrakcyjną oraz zrownowazona, wykorzystujacc przy tym lokalne rośliny i materiały. Kręte ścieżki piesze i rowerowe o długości 2,5 kilometra pełnią funkcję rdzenia projektu. Pozwalaja one przemierzać teren rozpoczynają od "bieguna" kulturalnego, zlokalizowanego na północnym-wschodzie, przez część sportowa w centrum oraz część skupiająca usługi na drugim końcu. W cześci kulturalnej, poza Parkiem Pamięci natrafimy na cztery ogrody tematyczne: Ouai des Brumes, Quai des Flots, Ou des Hommes i Oua des Vents. Każd z tych osobliwch miejsc ekspoje poetyckie walory loka os riwych miecto ska prybreine po. Atnostera poszczegolny miejsc

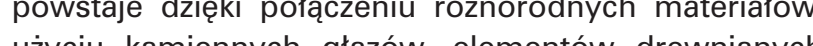
użyciu kamiennych glazow, elementow drewnianych i meta wami. Wszyst co to zostalo uzupelnione parą, fontannami wody, swiatlem i cieniem oraz odbiciami w wodzie. Meble miejskie zostaly zaprojektowane specjalnie dla tego projektu. Liniowy uklad lawek i oświetlenia przełamany jest meblami swobodnie rozsianymi po pejzażu. Czesść sportowa składa się z dwóch naziemnych boisk piłkarskich, dużych otwartych przestrzeni oraz wielozadaniowego toru. Ostatnia część projektu jest zbudowana wokół poprzemysłowego nadbrzeża, które skupia teraz usługi komercyjne. Kompleks składający się z wieży obserwacyjnej, pomostu połączonego z rzeką i wielofunkcyjnego pawilonu, stanowi ważny punkt $w$ tej przestrzen i przywraca wyobrażenie o molu rzecznym i nieodłącznych strukturach, które od wieków charakteryzowały port w Quebec. Pawilon Cageux jest obłożony drewnem eas for rest and recreation, and through their specific in the city. This makes connecting the city with th river one of the main challenges that cities located on rivers must face. However, it is essential for actions to be performed in a coordinated manner, with participation from local authorities, private developers, as well as the future users of the area to be transformed so that the changes that will occur will not be
nected from their expectations and needs.

2. Examples of the urban regeneration of riverside areas

2.1. Samuel-de Champlain promenade in Quebec ${ }^{3}$ One interesting example of the development of riverside areas as a result of an appropriately thought out functional layout and spatial connections, is the Promenade Samuel-De Champain in the city of Quebec in Canada. The promenade was built on the occasion of the city's four-hundred-year anniversary and is somewhat of a spatial monument to de Champlain. The traveller established a fort at this location, which has, over the years, transformed into a city with 500 thousand inhabitants. The design involved reclaiming a neglected industrial area and converting it into a public, recreational one, which would turn the city towards the river.

One of the most important things that the architects had to face was the redesign of the highway system, as highways crossed the entire length of the area. The atractive and sustainable, while using locally available plants and materials. The winding pedestrian and bicycle paths with a length of 25 kilometres play the part of the core of the design. They make it possible to traverse the area while starting at its "cultural" pole, located in the north-east, through the sports area in the centre to the part that concentrates serv end. In the cultural section, apart from Memorial Park, we can find four thematic gardens: Quai des Brumes, Quai des Flots, Quai des Hommes and Quai des Vents. Each of these peculiar places exposes the poetic qualities of the local riverside environment. The atmosphere of each of the places is created by a combination of various materials, the use of large stones, wooden and Corten-type metal elements along with domestic plant and trees. All of this was supplemented by steam, water fountains, light and shadow, as well as reflections in the water. Street furniture was designed specifically for this project. The linear layout of the benches, as well as about the landscape. The sports section is composed of two surface football pitches, large open composed a multi-purpose track. The final part of the project ar the buildings around the post-industrial quay, which is currently a concentration of commercial services. The complex, composed of an observation tower, a bridge connected to the river and a multi-functional pavilion constitutes an important point within the space and restores the idea of a river jetty and its indispensible structures, which have characterised Quebec's port for centuries. The Cageux pavilion is clad in timber both zarówno z zewnątrz jak i wewnątrz. W budynku znajduje ką za pomocą dużych przeszkleń. Taras o powierzchn 250m2jest $w$ stanie pomieścić różnorodne eksponaty i mogą być na nim organizowane wydarzenia związan z Promenadą Samuela de Champlaina. Wieża widokowa znajdujaca sie na południowych skraju Quai des Cageux posiada stalowa konstrukcje i kratownicowe burty i two rzy okno panoramiczne na rzeke oraz całość zatozienta

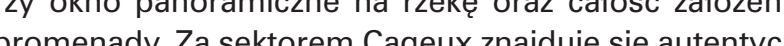
promenady. Za sekr rískich reliktów. Przestrzeń otaczaja

osiagnięciem Promenady Samuel de Champlain jest jej wkład w przywrócenie wyjątkowego, bogatego i zróżnicowanego ekosystemu przybrzeżnego do struktury miasta Quebec. Sieci rowerowe po obu stronach rzeki i wszelka aktywność w przestrzeni prome nady przyczyniają się do ożywienia ważnego dla histori nadbrzeza rzeki Lawrence i przynoszą korzyści zdrowotne dla użytkowników oraz gospodarcze dla miasta i jeg okolic.

2.2. Masterplan dla Central Delaware ${ }^{5}$

Kiedy ponad 300 lat temu, Wiliam Penn zakładał nowa kolonię, zdefiniowat Filadeffię jako "Greene Countrie Towne" - zieloną krainę rzek, potoków, bagien, pagorków i dolin. ${ }^{6}$ Niestety wraz z rozwojem regionu, miasto przeksztaciło się z zielonego zakątka w centrum przemysłu i handlu, z tętniącym życiem portem na rzece Delware. W ciaggu ostatnich 50 lat, tradycyjny przemysł opuścił te strefe pozostawiając nadbrzeże w słabej kondycji.

Celem nowego planu dla Central Delaware jest prze kształcenie głównego nadbrzeża Filadelfii w przedłużenie kwitnącego miasta. Architekci i urbaniści podjel próbe ponownego zwrócenia miasta w strone rzekl. Koncepcia opiera sie przede wszystkim na bogatej hitori regionu silnch walorach kulturowych mista, specyfice sasiednich dzelnic oraz otwatcia prestreni dla cyice ma

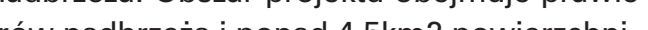

Główne założenie projektu opiera sie na przedłużaniu przylegających dzielnic w kierunku nadbrzeża i zagęszczeniu średniej i niskiej zabudowy, mieszczace różnorakie funkcje, obsługujące region. The Washington Avenue, Penn's Landing oraz Spring Garden są priory tetowymi terenami strategii rewitalizacji terenów przybrzeżnych. Na terenie The Washington Avenue projektanci zaproponowalr zlokalizowanie dodatkowej tkan mieszkaniowej w mieście. Dzielnica przeznaczona jest glownie pod apartamenty z widokiem na rzekę, ale rowniez podstawowe funkcje komercyjne. Penn's Landing od momentu powstania w 1970 roku, było miejscem organizowania wydarzeń publicznych takich jak koncerty, festiwale, a także najczęściej odwiedzanym fragmentem miasta przez osoby pragnące cieszyc się waloram inside and outside. The building houses a multi-functional space, which is con help of large glazed surfaces. The terrace, with a surface of $250 \mathrm{~m}^{2}$, is capable of hosting various exhibits and can host events associated with Promenade Samuel-De Champlain. The observation tower, which is lo cated on the southern edge of Quai des Cageux, possesses a steel structure and sides made from trusses, itself forming a panoramic window facing the river and Cacin Cageux sector there is a group of authentic archaeospace is surrounded by native, century-old trees 4

The main achievement of Promenade Samuel-De Champlain is its contribution to restoring the exChamplain is its contribution to restoring the ex-
ceptional, rich and varied riverside ecosystem to ceptional, rich and varied riverside ecosystem to works on both sides of the river and all manners of activity within the space of the promenade lead to the enlivening of this riverfront of the Lawrence River, which is an important historical site, and brings with th health-related benefits to users and the economy of both the city and its vicinity.

2.2. Masterplan for Central Delaware

When William Penn was founding one of the new colonies over three hundred years ago, he defined (t) land of rivers, streams, marshlands, hills and valment the city turned from a the region's developinto a centre of industry and commerce, with a busting port on the Delaware River. Over the past 50 years traditional industry left this area, leaving the riverfront in poor condition.

The goal of the new Central Delaware plan is the transformation of Philadelphia's main riverfront and extending the blooming city. Architects and urban planners made an attempt at once again turning the city towards the river. The proposal is based primarily on the rich history of the region, the strong cultura qualities of the city, the specificity of the neighbouring districts and opening the space to residents through appropriate "programming" of the riverfront. The area covered by the project includes over $10 \mathrm{k}$
tres of riverside areas and over $4,5 \mathrm{~km}^{2}$ of land.

The main objective of the project is based on extend ing the adjacent districts in the direction of the riverfront and increasing the density of low and mediumheight buildings which house various functions and Which's serve the region. The Washington Avenue, eas for the strategy of the regeneration of riverside areas. In the area of Washington Avenue designers proposed the placement of additional housing urban tissue. The district is mainly assigned for the construction of apartment buildings with a view of the river, but also basic commercial forms of use. Penn's Landing has, since its construction in 1970, been the site of public events such as concerts, festivals, in addition to being the fragment of the city most ofte visited by people wishing to enjoy the qualities of the 
rzeki Delaware. Nowy plan zakłada wzbogacenie oferowanych atrakcji poprzez lokalizacje nowych budynków kulturalnych o dużej skali, ktore zwiększyłyby dostepność, ale również zapewniły możliwość organizowania imprez przez cały rok. Obszar Spring Garden jest jednym z najbardziej złożonych, bogatych i wysoce rozwinietych odcinków nadbrzeża. Plan proponuje też utworzenie małych kwartałów zabudowy dla konwencjonalnej zabudowy mieszkaniowej, wsod systemu ulic o waskiej budowy mieszkaniowej, wśrod systemu ulic o wąskie

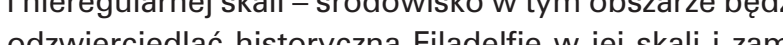
odźn

Projekt zakłada utworzenie parków zlokalizowanych co 800 metrów wzdłuż nadbrzeża na przedłużeniu kluczowych ulic, aby ograniczyć długość dojścia mieszkańców do terenów zielonych i dodać wartości sasiadujacym dzielnicom. Parki beda różnić sie charakterem, działaniami projektowymi i bezpośrednim otoczeniem Łącznie przewiduje się utworzenie dziesięciu parków wzdłuż nadbrzeża, które będą uzupełniane publicznym przestrzeniami otwartymi. Całość założenia bẹdzie połaczona wielofunkcyjną siecią ścieżek dla rowerów i i pieszych. szych. Dodatkowo projekt zaleca wprowadzenie istotnych zmian w systemie transportowym miasta, w cel zapewnienia lepszej dostępności nadbrzeża dla pieszych i rowerzystow, wprowadzenie licznych przejść podziemnych w kierunku miasto-rzeka, a takze podniesienie w kilku miejscach jezdni samochodowej ponad poziom terenu.

Masterplan dla Central Delaware jest dobrym przykładem kompleksowego planu rewitalizacji zaniedbanego terenu poprzemysłowego. Strategia zakłada połaczenie działań publicznych i prywatnych w celu sfinansowania projektu. Dzięki odgórnemu planowi możliwe jest stworzenie spójnego fragmentu tkanki miejskiej, która przywróci rzekę miastu.

\subsection{HafenCity ${ }^{7}$}

Powstająca w Hamburgu nowa dzielnica HafenCity to obecnie jeden z najambitniejszych projektów rewitalizacji terenów nadrzecznych w Europie. Koncepcja obejmuje ponad 155 hektarów dawnego portu rzecznego oraz gazowni. Założenie powiększy aktualne centrum miasta o 40 procent. Plan miał na celu przede wszystkim wykreowanie wizerunku Hamburga jako dynamicznie rozwijającego się miasta oraz zbudowanie wysokiej jakości przestrzeni życia dla mieszkanców. Plan przygotowano na podstawie zwycięskiego projektu konkursowego zespołu Astoc, Hamburgplan i Kees Christiansee. ${ }^{8}$ Przy tak ogromnej skali założenia ważne było podzielenie realizacji na etapy, by stopniowo integrować HafenCity z pozostałą częścią miasta. Fundamentalnym założeniem uchwalonego w 2000 roku planu, na podstawie którego budowane jest HafenCity, jest wymieszanie funkcji rekreacyjnych, mieszkalnych oraz biurowych. Dzięki temu udało się uniknąc kwartałów wyłącznie "sypialnianych", czy też ośrodków biurowych, które wieczorami pusto-
Delaware River. The new plan assumes the enrichDefle offered through the placewould increase accessibility, as well as provide the possibility of organising events throughout the entire year. The area of Spring Garden is one of the most complex, rich and highly developed sections of the riverfront. The plan proposes the creation of small urban blocks for conventional residential buildings scale a system of streets wilh a narrow and reguls torical Philadelphia in its scale and concept.

The design assumes the establishment of parks located every 800 metres along the riverfront, at the extensio of key streets, in order to reduce the length that resdents would have to travel to reach green areas and to increase the value of the neighbouring districts. The parks will each have a different character, design and immediate vicinity. In total, ten parks are being planned for placement along the riverfront and are to be supplemented by public open spaces. The entirety of the layout will be connected by a mixed-use network of pedestrian and bicycle paths. In addition, the design recommends the introduction of significant changes in the city's transport system, the introduction of numerous underground passages in the direction between the city and the river, as well as elevating the carriageways of streets above ground level in some areas.

The Central Delaware Masterplan is a good example of a comprehensive plan of the urban regeneration sumes a combination of public and private efforts in order to finance the project. Thanks to a general it will be possible to create a coherent fragment urban tissue that will restore the river to the city.

2.3. HafenCity ${ }^{7}$

The new district called HafenCity that is currently being built in Hamburg is one of the most ambitious urban regeneration projects for riverside areas in Europe. The project covers over 155 hectares of a former river port and gasworks. The layout will increase the current city centre by 40 percent. The plan was primarily meant to create an image of Hamburg as a dynamically developing city and build a high-quality living space for its residents. The plan was prepared on the basis of a winning competition design by the Astoc, Hamburgplan and Kees Christiansee team ${ }^{8}$. With such an immense scale of the project, it was important to divide carrying it ou into stages, in order to gradually integrate HafenCity assumption of the plan that was approved in 2000 , on the basis of which lan that was approved in 2000, on recreation residential and office-related forms of use. Thanks to this the plan managed to avoid urban blocks exclusively fulfilling the role of "bedroom blocks" or of fice centres, which become abandoned in the evening. A lot of attention is being paid to the quality of common spaces, which are primarily aimed at pedestrians and cyclists. The new district is being built in the immediate vicinity of the river, in areas that are in danger of flooding, which is why it was necessary to address the szeją. Dużą wagę przykłada się do jakości przestrzen wspónch, które nastawione są przede wszystkim na 作 dlatego też konieczne okazało się rozwiazanie kwest ochrony przeciwpowodziowej. Zrezygnowano $z$ two rzenia kolejnego wału przeciwpowodziowego dla mia sta. W zamian postanowiono wznieść cała dzielnice 7-8 metrów ponad poziom lustra wody. Partery budynków stojacych na nadrzejoch przezn. Paczone bostynkó parkingi, albo lokażytkowe, które w razie powodz parkini, abo loka uiykowe, koczon zaze powodz dziowymi Różnica poziomów ulic i nadbrzė̇y okazo-

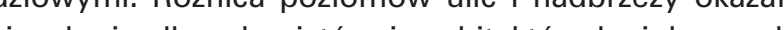
se okaja da urber stwzence Terodze am Polr olne ku wodzie - Tarasy Magellana, Tarasy Marco Polo oraz Plaza Vasco da Gasy. Panki i place mają łącznie 27 hektarów, a obiekty do nich przylega jące posiadają uslugowe partery o wysokości 5 metrow. Latwy i szybli dostęp do rewitalzowa zapewnić linia metra biegnąca przez całą dzielnicę. Do datkowo w przyszłości planowane jest połączenie ze stacją naziemną szybkiej kolei aglomeracyjnej. Koncepcja zapewnia rownież atrakcyjną i czytelną sieć połączen pieszych i rowerowych. W projekcie zakłada się aż 70\% tras przebiegających niezależnie od ciągów komunikaci kołowej. Ponadto planowane jest ograniczenie udziału transportu samochodowego na tym terenie. 'Wysokiej jakości architektura wynika z obligatoryjnych konkursów architektonicznych na każdą nową inwestycję. Korzyścia takiego rozwiązania jest to, że architektura poszczególnych obiektów nie jest monotonna, choć spójna. Najbardziej prestiżowym obiektem jest Elbphilharmonia, zaprojektowana przez biuro Herzog de Meuron. ${ }^{10}$ Sala koncertowa na 2100 miejsc została zaprojektowana jako szklany namiot", który jest nadbudowa budynku istniejacego. Poza gtówna funkcia mieszcza sie tu sale konferencyine, Spa hotel oraz taras widokowy. Filharmoni mierzy 110 metrow i jest jednym z naiwyżych obiektów w mieście.

Tworzona z wielkim rozmachem dzielnica, która posiada wysokie walory urbanistyczne i architektoniczne, przyciąga nowych mieszkańców. Rewitalizacja ta jest niewąpliwie przykładem konsekwentnego realizowania założeń zróżnicowanego rozwoju. Hamburg dzięki HafenCity odzyskał utracony przez przemysł dostęp do Łaby.

\subsection{Bulwary Wiślane w Warszawie}

W ostatnich latach w Polsce coraz częściej widzi się realizacje majace na celu rewitalizację obszarów nadrzecznych. Najbardziej znanym aktualnie przykładem jest podzielona na etapy przebudowa bulwarow wislanych w Warszawie. Od roku 2013 przeprowadzono działani na terenach między Mostem Gdanskim a Mostem Swiętokrzyskim w dwoch etapach. Ostatnio otwarty odcinek w 2017 roku został wykonany na podstawie projektu biura RS Architektura Krajobrazu." matter of flood protection. The construction of another instead, it was decided to have the entire district be elevated 7-8 metres above the surface of the wate

The ground floors of buildings located along the riverfront were assigned for parking lots or premises, which are secured by special flood-preventing bulkheads. The difference in level between the streets and the wharfs turned out to become an opportunity for tractive spaces. Terraces descending towards the water like amphitheatres were built: Magellards the waMarco Polo's Terras and Plaza Vageln's Terraces, parks and squares have a combined sufface area of 27 hectares and the buildings adjacent to them fea ture commercial spaces on the ground floors with a height of 5 metres.

Quick and easy access to the area undergoing regeneration is to be provided by an underground railway line running across the entire district. In addition, a connection with a surface station of the rapid transit metropolitan railway is planned in the future. The plan also provides an attractive and legible network of pedestrian and bicycle connections. The plan assumes that as much as $70 \%$ of paths will be running independently of vehicular circulation paths. Furthermore a reduction in the share of car traffic in the area is planned. The area's high-quality architecture is a result of obligatory architectural competiThe fore and every new development project. of the individual buildings is not monotonous, while remaining coherent. The most prostigious building is Elbphilharmonia, designed by Herzong \& de Meuron ${ }^{10}$. This concert hall with 2100 seats was designed as a "glass tent", which has been built on top of an existing building. Apart from its main functions, it houses conference halls, a Spa, a hotel and an observation deck. The Philharmonics is 110 metres in size and is one of the tallest buildings in the city.

The grand district, which has high urban and architectural qualities, is attracting new residents. This urban regeneration project is also undoubtedly a example of the consistent implementation of the precepts of sustainable development. Thanks ed access to the Elbe which it lost due to industry.

2.4. Vistula River Boulevards in Warsaw

In recent years we have been seeing built projects eanten in Poland. The currestly meas increasingly ample is the redevelopment of the Vistula River boulevards in Warsaw, which has been divided into three stages. Since 2013 development is seen in areas between Most Gdański and Most Świetokrzyski, in two stages. The section that was opened in 2017 was developed in accordance with a design by RS Architektura Krajobrazu'1.

The design's objective is to create a unique public space, as well as to restore the close and legible rela tionship between the city and the Vistula. On the ur- 
Projekt ma na celu wykreowanie unikalnej przestrzeni publicznej, przywraca ścistą i czytelną relacje z Wisłą. W skali urbanistycznej teren został powiązany z miastem za pomocą sekwencji lasów usytuowanych na zakończeniach najważniejszych ciągów miejskich. Bulwar pełni wieloraką funkcję: rekreacyjną, komunikacyina, społeczna, ale również reprezentacyina przez cały rok. Przestrzeń nadbrzeża została podzielona na cztery gtówne strefy Jedna jest bulwar spacerowy z brzegiem glówne strefy. Jedna jest buswar spacerowy z brzegiem przystankami tramwaju wodnego. Nastepna strefa jest

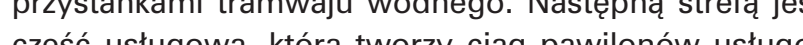
częsc uslugowa, hora worzy ciąg pawilonów usługośla, powst bulwar rekreacyny z placen zabaw, plaza sla, powsta bulwar rekreacyjny z placem zabaw, plaż $z$ barem oraz an za wy larzenia plenerowe. Ostapha czescia jest ogrod zywej rzeki zlokalizowany na wysokości Centrum Nauki Kopernik (CNK). ${ }^{2} W$ tej strefie projektanci zagospodarowali brzeg rzeki, ktorry ukazuje nadrzeczne piętra roślinne. Architekci nie chcieli stworzyd bulwaru z oczywistym programem, zdominowanym przez funkcję komunikac pieszo-rowerowej oraz biernego wypoczynku. By temu zapobiec wprowadzono bezpośredni dostęp do wody kaskadę przy pomniku Syrenki, czy też tarasowe nadbrzeże przy CNK, gdzie niezależnie od stanu rzeki możn bezpiecznie dojść do wody i jej dotknąć. 1

W ostatnim czasie rozstrzygnięto konkurs na ostatn etap rewitalizacji bulwarow Wiślanych. Pierwsza nagrodę zdobyło biuro projektowe WXCA. ${ }^{14}$ Warszawskie biuro zaprojektowało obszar, który będzie się różnił od pozostałych, głównie spacerowych. Teren między Mostem Świętokrzyskim a Cyplem Czerniakowskim bedzie obszarem o miejskim charakterze. Projekt obejmuje m.in. stworzenie porośniętej bluszczem hali, przeznaczonej na cele wystawiennicze oraz kulturalne, a takì punktowca, w którym umieszczono fukcje hotelowa. Poza duzymi obiektami kubaturowymi w projekcie znaIazło sie wiele przeszklonych pawilonów które pomieszlazło siew

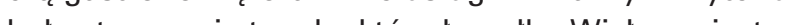

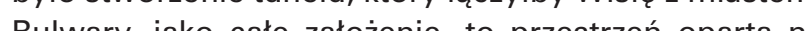
międzynarodowych

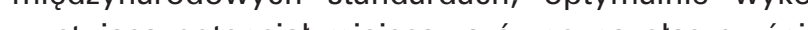

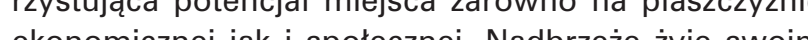
ekonomicznej jak i spolecznej. Nadbrzeze żyje swoim życiem, jednocześnie jest częscią miasta i jest z nim sciśle powiązane za pomocą bezkolizyjnych połącze pieszych i rowerowych. Stworzenie ogólnodostępne przestrzeni nad rzek, bogatej w funkcje i niekonwencjonalny program pozwoli ożywić tę część nadbrzeż o różnych porach dnia i roku, a co za tym idzie stworzy kolejne miejsce dla mieszkańców, gdzie mogą spędzic swój wolny czas.

3. Projekt „EKO EXPO” - wystawa eko-architektury Przedstawione powyzej rozwazania stały się jednym z punktów wyjścia do projektu założenia „EKO EXPO nad Wisłą w Krakowie - Nowej Hucie, który to projekt ban-planning scale, the area has been linked with the of the most importar fulfils many functions: a recreational, circulation-related, social, as well as a representative one, throughou the entire year. The space of the riverfront was divided into four main zones. One of these is a pedestrian boulevard with a wharf for anchoring boats, along with floating restaurants and water tram stops. The nex zone is the commercial part, which is formed out of A recreation boulevard with a playground a a bar and an amphitheatre was created near Powiśle. A space for open-air events has been established here The final part is a living river garden, located near the Copernicus Science Centre (CNK) ${ }^{12}$. In this zone the designers developed the shore of the river, which shows the altitudinal zonation of riverside plants. The architects did not want to create a boulevard with an obvious programme, dominated by pedestrian and bicycle circulation and a passive recreation zone. I order to prevent this, direct access to water was introduced, as well as a cascade near the Mermaid monument, in addition to a stepped shore near the CNK where, regardless of the river's water level, we can safely find ourselves near water and touch it

The competition for the final stage of the urban re generation of the Vistula River Boulevards has recently been concluded. The first prize was awarded fice designed design office ${ }^{14}$. The Warsaw-based ofing primarily walking-based ones. The site between Most Świetokrzysi and Cypl Cz. The site between an area with an urban character. The design features, among other things, the creation of a vine-covere hall meant for cultural functions and exhibitions, as well as a tower building which will house a hotel. Apart from large buildings, the design also includes numerous glazed pavilions meant to feature gastronomic establishments and other services ${ }^{15}$. The creation of a tunnel that would connect the Vistula with the city was an important criterion. The boulevards, as a whole, are a space based on international standards, optimally making use of their potential both on the economic and social plane. The riverfront live independently, while at the same time being a part of the city and is closely tied with it through safe pedestrian and bicycle connections. The establishmen of a generally accessible space along the river, with a variety of functions and an unconventional prog the riverfront at different times of the day and the year and, as a result, will create another place for the residents to spend their free time.

\section{3. "EKO EXPO" - eco-architecture exhibition}

The discussion presented above became one of the starting points for the design of the "EKO EXPO" Huta, which was developed as a Master's project at the Faculty of Architecture of the Cracow University of Technology ${ }^{16}$. został wykonany jako praca dyplomowa magisterska na Wydziale Architektury Politechniki Krakowskiej. Teren inwestycji znajduje się we wschodniej części Miasta Kraków w XVIII Dzielnicy - Nowa Huta. Obszar obe muje około 100 tysięcy $\mathrm{m} 2$ zaniedbanego terenu nad rzeka Wisła. Duża odległość od centrum miasta, słaba komunikacja zbiorowa oraz brak odpowiedniego progra mu funkcjonalnego sprawia, że teren ten, a nawet miesz czacy się w centralnej jego cześci Yacht Klub Nowa Huta nieczęsto odwiedzany jest przez mieszkańców.

3.1. Teren

Obszar położony nad Wisłą mógtby być prężnie rozwijającym się ośrodkiem rekreacyjno-wypoczynkowym w tej cześci Krakowa. Niestety utrudnione połączenie $z$ centrum, a także innymi cześciami Krakowa, w tym samej Nowej Huty, sprawia, iż potencjat ten jest niewykorzystany. Linie autobusowe kursujące $w$ najbliższe okolicy nie są w stanie zapewnić odpowiedniego przepływu osób, połączeń jest zbyt mało. Duża odległość od przystanku tramwajowego, sprawia, iż ten szybki sposób poruszania się po miescie jest w tym wypadku nieatrakcyjny. Jeszcze do niedawna na teren inwestycji docierał tramwaj wodny, który ma bezpośrednie połączenie $z$ centrum miasta. Niestety względy ekonomiczne oraz brak odpowiedniej infrastruktury, która przyciągnęłaby mieszkańców i turystów sprawiły, że przystanek tramwau wodnego zostal zlikwidowany. Innym rozwiazaniem jest dotarcie na miejsce komunikacją indywidualną samochodem bądź rowerem. Obecnie na terenie Yach Klubu mieści się parking na kilkanaście samochodów, a wzdłuż Wisły przebiega ścieżka rowerowa.

3.2. Założenia projektowe

Podstawową ideą projektu jest stworzenie atrakcyjne przestrzeni publicznej i społecznej, która podniesie walory brzegu Wisły w tej części Krakowa. By to osiągnąc ważne jest utworzenie odpowiedniego programu funkcjonalnego, który odpowie na zapotrzebowanie zarówno mieszkańców, jak i turystów. Ogólne założenia musza być dostosowane dla wszystkich, bez względu na wiek czy grupe społeczną. Główną funkcja projektowanego terenu jest funkcja rekreacyjno-wypoczynkowa, typowa derenu jest funkcja rekreacyjno-wypoczynkowa, typowa nała przestrzeń do spędzania wolnego czasu, zarówno aktywnie jak i biernie. Utworzenie licznych miejsc do spacerowania, uprawiania sportów, czy tez siedzenia spacerowania, uprawiania sportów, czy tez siedzenia i odpoczynku jest niezbędne by ten cel osiagnąac. Ważne jest zrozznicowanie tych atrakcji, by każdy z potencjalnych użytkowników mógi znaleźc cos odpowiedniego dla siebie. Niebywale istotne, dla idei projektu, jest stworzenie przestzeni uniwersalnej, skierowanej dla wszystkich, w tym dla niepełnosprawnych osób. W tym cel zadbano by każa atrakcja była dostosowana do osó o różnym stopniu i rodzaju niepełnosprawności. Kolejnym ważnym załozeniem było połączenie głównej funkcji (rekreacyjno-wypoczynkowej) z funkcją edukacyjną.
The project site is located in the eastern part of the city of Krakow in the Eighteenth District-Nowa Huta. The site covers around 100 thousand $\mathrm{m}^{2}$ of neglected areas near the Vistula River. The large distance to the centre of the city, very limited public transport options and the lack of an appropriate functional programme cause this area, along with the Nowa Huta Yacht Club that is located in its central part, to be
arely visited by residents

3.1. The site

The site located along the Vistula River could be a dyin this part of Kraking centre for rest and recreation nection with the centre, as well as with other parts of Krakow, including Nowa Huta itself, cause this potential to remain untapped. Bus lines operating in the immediate vicinity are not capable of providing an appropriate flow of people, while the number of connections is insufficient. The large distance to the tram stop makes this rapid form of transport within the city unattractive in this case. Until quite recently a water tram provided a direct connection with the centre of the city. Unfortunately, economic considerations, as well as the lack of appropriate infrastructure tha could attract residents and tourists, caused the water tram stop to be shut down. Another solution is the use of individual means of circulation-a car or a bicycle-to reach the site. The Yacht Club currently a bicycle path runs along the Vistula River.

\subsection{Design objectives}

The main idea of the design is the creation of an attractive public and social space that would improve the qualities of the Vistula River shore in this part of Krakow. In order to achieve this, it was important to formulate an appropriate functional programme that could be an answer to the needs of both residents be adapted to everyone, regardless of age or socia group. The primary function of the area covered by the design is that of rest and recreation, typical for these types of solutions. Riverside areas are the perfect spaces to spend free time in, both actively and passively. Creating numerous places to go on walks, engage in sports or sit down and rest is necessary in order to meet this objective. It is important to provide a variety of these attractions so that every potentia user could thind something appropriate for them. wo create a universal space, addressed to all including persons with disabilities. To this end overy attraction was designed to be adapted to persons of different ages and different types of disability. Another important assumption was the combination of the main function (rest and recreation) with education. The idea of creating the "EKO EXPO", a space for the exhibition of environmentaly friendly architecture, is an attemp at finding an interesting, cyclical event that would attract both architecture enthusiasts and residents who could gain knowledge about the contemporary 
Idea stworzenia „EKO EXPO”, przestrzeni wystawy ekogo, cyklicznego wydarzenia, który przyciągnie zarówno entuzjastów architektury, ale również mieszkańców, którzy w ten sposób mogą zdobyć wiedzę o współczesnych osiągnięciach budownictwa. Edukacja o architekturze i jej otoczeniu jest wyjątkowo istotna, gdyż dziś wszyscy użytkownicy przestrzeni decyduja o tym jak wyglądaja miasta i obiekty w nich sie znajdujace. Pawilony projekmiasta i obiekty w nich się znajdujace. Pawilony projektowane zentow ć eko pozne rozwią a Kàdurą mają prepench eko pona np. gastronomia, kluby gic tów, spotkan, imprez.

Ideą projektu jest również wyeksponowanie naturalnej Wisty obfiu naw rożn grajobrazu. Tereny nadbrzeżne Wisły obfitują w rožne gatunki roslin. Dlatego też projek zakłada utworzenie specjalnych stref z roślinnością tęgową, charakterystyczną dla tego obszaru. Przestrzenie te pozwalają na do
ków bulwaru. $W$ tej ków bulwaru. W tej strefie zaprojektowano również trzy pomosty, ktore pozwalają odejsc bezpiecznie od brzegu "w rzekę" i poznać ją z innej perspektywy. Dodatkowo pomosty są polączone z wieżą widokową, która zapewnia wspaniale widoki na oba brzegi Wisły. Wažnym zabiegiem funkcjonalno-przestrzennym jest połączenie dwóch naturalnych stref w tej części miasta: Lasku Mogilskiego i Wisły. Niestety obecnie przestrzeń lasu oddzielona jest od rzeki wałem przeciwpowodziowym oraz ulica. W celu powiązania dwóch przestrzeni zielonych stworzono przejście podziemne przez wał (wyposażon w grodzie przeciwpowodziowe) i promenade, która prowadzi wprost na mała scene amfiteatru na wodzie. Architektura pełni istotna role w kształtowaniu przestrzen Dlatego też waże jest, by proponowany obiekt architektoniczny centrum wystawienniczo-konferencyinego, który uzupetni program calogo zatozin integrowa i spajet caly zainwestowany obszar.W osiagnieciu tego i spajal caly zain westowany obsza. W osiągnięciu tego i uktad funkcjont a tez forma obiektu. Zaprojak i wakn pietrcjy budynek swoja bry integrue zieko-

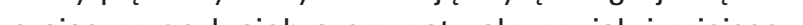
czajacym go krajobrazem naturalnm, jak i miejscowa architektura. Zastosowane przekrycie obieku bazujace na linii lamanej nawiązuje do lokalnej architektury a duże przeszklenia, szzzególnie parteru, otwierają sie na otaczający krajobraz oraz optycznie przedluzają prze strzeń wystawową na teren całego założenia bulwarów.

\section{Podsumowani}

Rewitalizacja terenów nadrzecznych jest, niewątpliwie jednym z największych wyzwan urbanistycznych dla wspołczesnych miast. Dostrzegane są korzyści zarówno ekonomiczne jak i społeczne wynikające z odpowiednio zagospodarowanego terenu nabrzeża rzek poprzez zainteresowanie inwestorów, turystów, ale przed wszystkim samych mieszkańców miasta. Doliny rzeczne achievements of construction technology. Education as today all of the users of a how cities and the buildings inside them will look. The pavilions designed on the exhibition grounds are meant to be temporary structures, which, apart from attractive architecture, are meant to present environ mentally friendly solutions. Furthermore, each of the pavilions is meant to house functions supporting the (ithmg of the entire site, such as gastronomic estabworkshops, meetings and events.

Another idea behind the design is the highlighting of Ane river behind the design is the highlighting of riverside areas of the Vistula are rich in many different plant species. This is why the design includes the establishment of special zones with flood-mead ow plants, which are characteristic of this area. These spaces make it possible for the users of the boulevard to experience nature. Three bridges that make it possible to safely go over the river and get to know it from a different perspective were also designed in this zone. In addition, the bridges are connected with an observation tower that provides excellent views of both shores of the Vistula. Another important functional and spatial procedure is the connection of the two natural zones of this part of the city: Lasek Mogilski and the Vistula River. Unfortunately, at the moment the space of Lasek Mogand a street. In order for the connection between these two green spaces to be possible, an under ground pase spaces the be possible, an underwith flood-preventing bulkheads) was designed, as well as a promenade which leads straight to a smal amphitheatrical stage placed on the water. Architecture plays an important part in the shaping of space. This is why it is important for the proposed building of the conference and exhibition centre that supplements the programme of the entire complex to integrate and bind the entire area being developed. Both an appropriately selected programme and functional layout and the form of the structure are meant to aid in achieving this. The two-storey building blends in with the surrounding natural landscape, as well as the local architecture, through its massing. The covering of the structure, based on a zigzagging line, is a reference to local architectre, while the large glazed surfaces, particularly on the ground floor, open up towards the surrounding into the entire area of the boulevard complex.

\section{Conclusions}

The urban regeneration of riverside areas is, without a doubt, one of the greatest challenges for contemporary cities in terms of urban planning Both economic and social benefits arising from appropriately developed riverside areas in the form of interest from developers, tourists and-primarily-the residents of the cities themselves, are clearly observable. River valleys have become par- stały się szczególnymi obszarami w strukturze miasta ogromny potencjał rekreacyjny. Proces przywracania rzeki miastu jest procesem złożonym i trudnym jednak dzięki współpracy planistów, włodarzy miast prywatnych inwestorów i mieszkańców możliwe jest wykreowanie przestrzeni, która wzbogaci miasto stworzy dodatkowe miejsca wypoczynku i rekreacji. Projekt dyplomowy "EKO EXPO” w Krakowie próbuje sie w ten nurt wpisać. Dzieki odpowiednio zaprogramowanej funkcii, rowiazaniom przestrzennym i komunikacyinym z centrum miasta, a także dzieki pieknu przestzen zięknu przestrzeni, cereng nadrecze skiej zanichanie dzialn majacych nacelu rewizaskiej. Zaniechanie dzilan mających na celu rewitalizacę rzek w miastach jest nis go czynnika miastotwórczego w historii urbanistyki.

PRZYPISY

S. Bernat Rewitalizacia dolin rzecznych w miastach Prace Komisji Krajobrazu Kulturowego T.VII, Sosnowiec 2007
2L. Trzaski, A. Polaczek, M. Koppernik, P. tabaj, W. Szendera Rewitaliza
cia miejskich przestrzeni nadrzecznych w Polsce - ocena planowannia cja miejskich przestrzzeni nadrzecznych w Polisce - ocena planowania
iw wrozeń w potudniowej cześsci kraju, Prace naukowe GIG, Gónictwo isrodowisko, 1/2010, s. 59-71

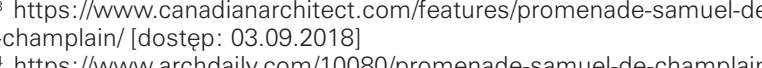

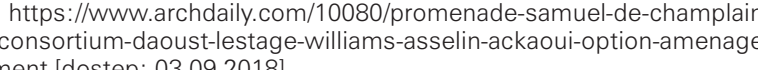

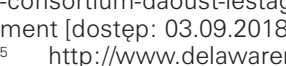

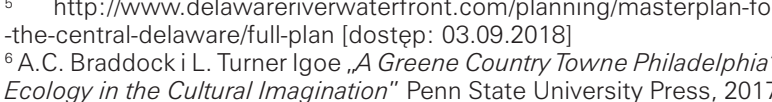
s.13

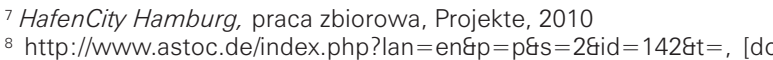

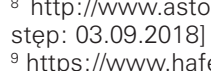

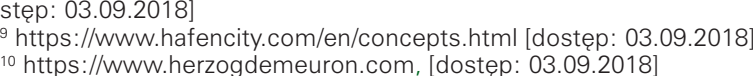

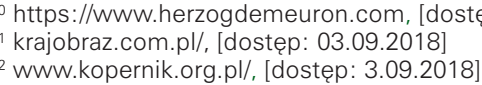

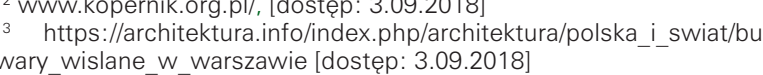
Wary_wislane-w-Warszawie [dostep: 3.09 .2018
"www.wxca.pl, [dostepp: 3.09 .2018$]$

(dostep 16 Autor dyplomu: Konrad Piwowar, promotor: dr hab. inż. arch. Magda-
lena Jagietto-KowalcykK, proff. PK , promotor pomocniczy: dr inż. arch.
Bogdan Siedlecki, Kraków 2018

BIBLIOGRAFIA

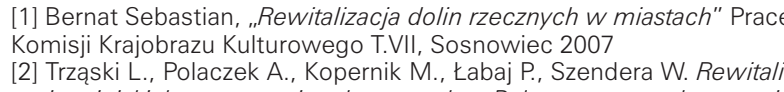

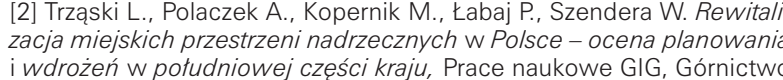

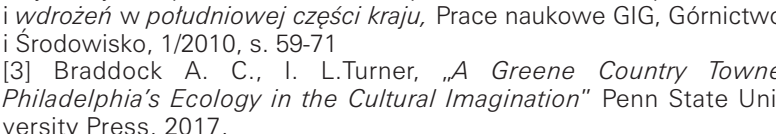

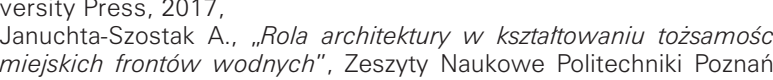
skiej, Architektura i Urbanistyka, Poznań, 2009

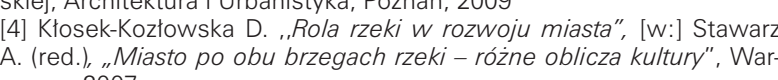
szawa, 2007
[5] Lorens P., Rewitalizacija frontów wodnych jako element procesu
odnowy miast ( (W:- KK. Markowski (red). Przestrzeń w zarzadzaniu roz ticularly important areas within the structure of cities thanks to their natural quallies and posesss an immense potential for recreation. The processes of restoring a river to a city are complex and difficult, however, thanks to the cooperation between planners, municipal governments, private developers and residents it is possible to create a space the for rest and recreation. The "EKO EXPO" Master's project in Krakow attempts to become a part of this tendency. Thanks to an appropriately programmed function, as well as its spatial solutions and circulation connections with the centre of the city, in addition to the beauty of the space, riverside areas can become an essential cultural and recreationa site within urban space. Refraining from efforts to revitalise rivers in cities means squandering the potential of the city, as well as underestimating the of urban planning.

ENDNOTES

'S. Bernat Rewitalizacja dolin rzecznych w miastach Prace Komisi 2L. Traaski, A. Polaccer, M. Kopernik, . tabaj, W. Szendera Rewita-
lizacia miejskich przestrzeni nadrzecznych w Polsce - ocena plano-

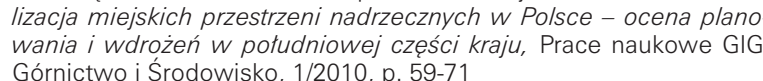
3 https:://Www.canadianarchitect.com/fe 2018] 4h.t/Mww.archdaaly.com/10080/promenade-samuel-de-champlanagement [retrieved on: 03.09.2018]
http://www delawareriverwaterfro C. - A.C. Braddock i L. Turner Igoe. AA Greene Country Towne
Philadelphia's Ecology in the Cultural Imagination" Penn State University Press, 2017, p. 13

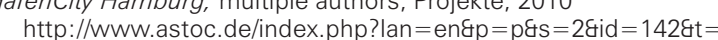
[retrieved on: 03.09.2018]

https:/Wwithenty.com/en/concepts.html [retrieved on: 03.09.2018

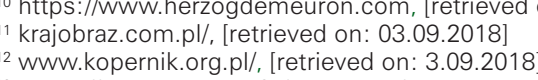

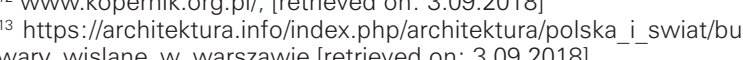

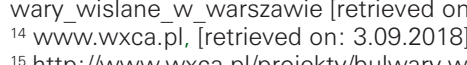
pl/proiekty/bulwary-wislane-warszawa//retrieve

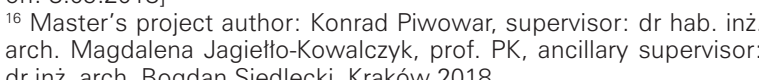

BIBLIOGRAPHY [1] Bernat Sebastian, "Rewitalizacja dolin rzecznych w miastach" Pra-
ce Komisji Krajobrazu Kulturowego TVVII, Sosnowiec 2007
[2] Trzaski L., Polaczek A., Kopernik M., tabaj P., Szendera W. Rewi-

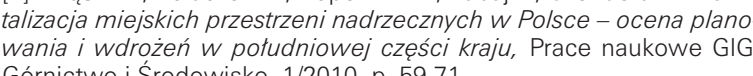
[3] Braddock A. C. C. I. L. Turner. A G Greene Country Towne
Philadelphia's Ecology in the Cultural Imagination" Penn State Uni-

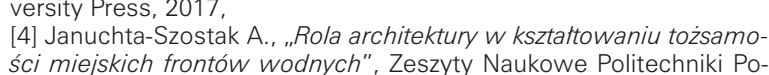

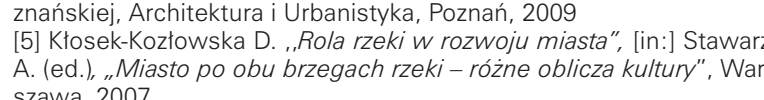
Szawa, 2007 , Rewitalizacia frontów wodnych jako element procesu
[6] Lorens P.,
odnowy miast, lin:Jk. Markowski (ed.), ,Przestrzeń w zarządzaniu roz- 
Wojem regionalnym lokalhym", , Biuletyn KPZK PAN, z. 211, PG. 2004
[6] Panacewicz A... Rzeka w wraiobrazie przzestrzennym miasta. Próba okre-

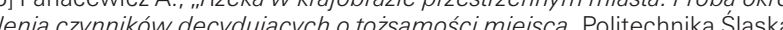

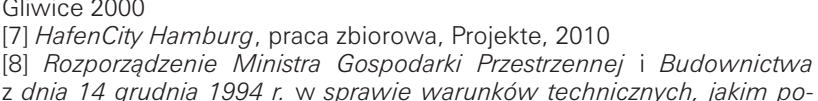
2 dnia 14 grudnia $1994 \mathrm{r}$. w sprawie warunków technicznych, jakim po-

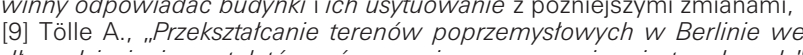
dfug , dziessieciu postulatow zrownowazonego rozwoju miast nad woda" Problemy Ekologini Krajobrazu, t. XXIV. s.., Berlin, 2009 '

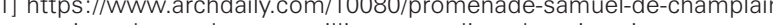

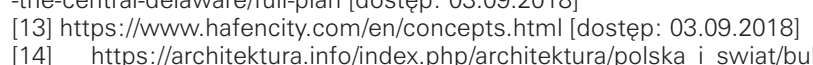
wary-wislane-warszawa/ [dostep: [16] ht htps://henninglarsen.com/en/news/archive/2018/03/15-gdansk-
-embrace-the-future-with-major-urban-development-project
[dostęp 4.09.2018] [17] http: //Www
step: 03.09.2018
[18 htps:/Www

n.com, [dostep: 03.09.2018

[19] krajobraz.com. pl//, [dostep: 03.09.2018]
201 www.kopernik.org. pll/, [dostęp: 3.09.2018]
Wojem regionalnym lokalnym", Biuletyn KPZK PAN, b. 211, PG. 2004 [8] HafenCity Hamburg, praca zbiorowa, Projekte, 201 of the 14 th of December 1994 concerning the technical conditions ges ges. Tölle A., , Przeksztactanie terenów poprzemystowych w Berlinie wedtug ",dziesieciu postulatón zrównowazonego rozwoju
miast nad wodą", Problemy Ekologi Krajobrazu,vol. XXIV. p., Berlin. 2001, [11] hittps://Www.canadianarchitect.com/features/promenade-sa
muel-de-champlain/ [retrieved on: 03.09 .2018 ] [12] https://Wwww.archdaily.com/10080/promenade-samuel-de-
-champlain-consortium-daoust-lestage-williams-asselin-ackaoul-

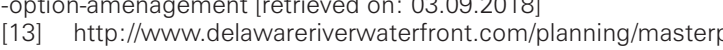

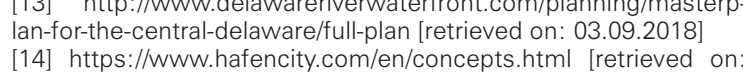
03.09.2018

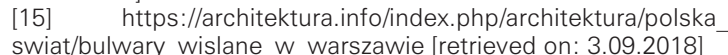

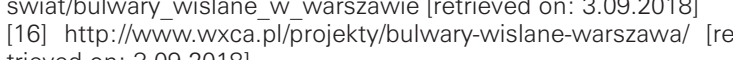
[17] hitps: //henninglarsen.com/en/news/archive/2018/03/15

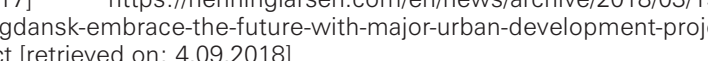

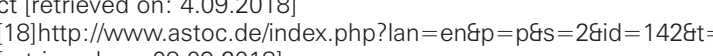
[retrieved on: 03.09.2018

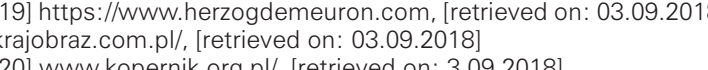
.09.2018

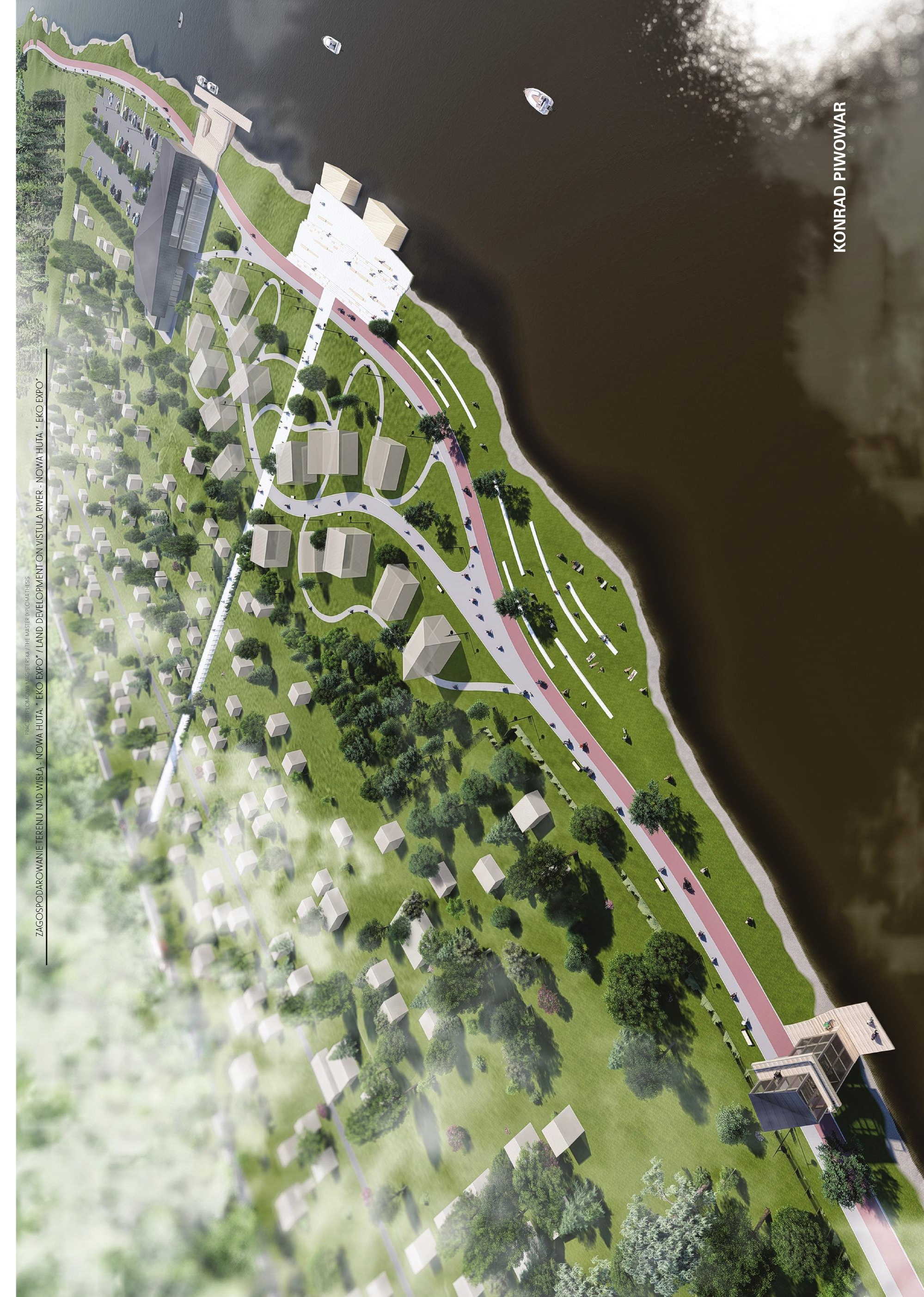




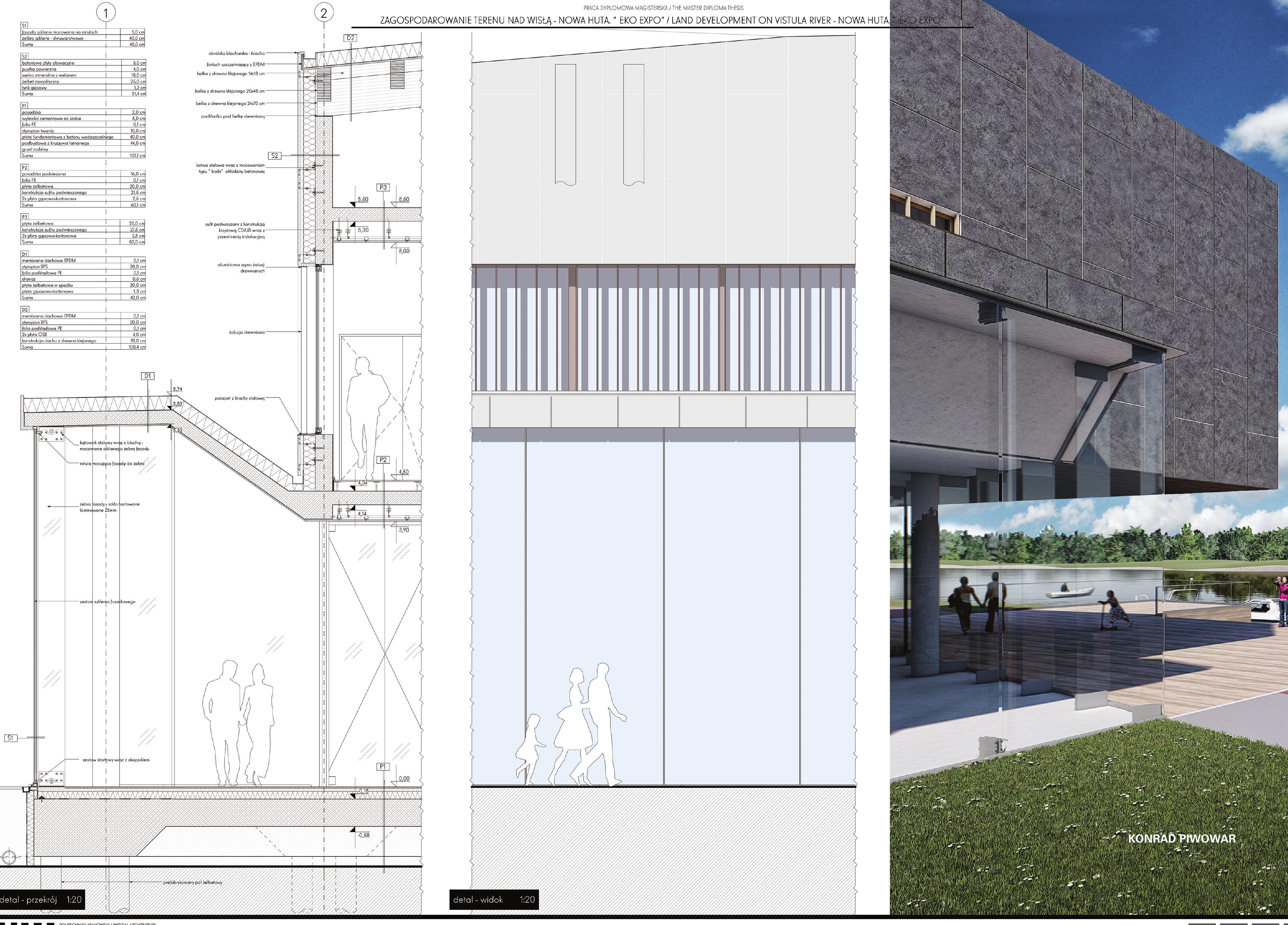

